UDC 636.085.53; 633.31-181

COBISS.SR-ID: 220310796

Original research paper

Acta Agriculturae Serbica, Vol. XX, 40 (2015); 155-163

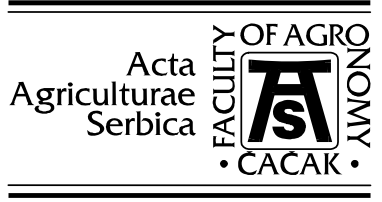

\title{
Yield and cost-effectiveness of alfalfa hay production as dependent on fertilization
}

\author{
Nikola Bokan ${ }^{1}$, Goran Dugalić ${ }^{\text {, Slobodan Katić }}{ }^{\text {, Dragan Milić }}$, \\ Sanja Vasiljević ${ }^{2}$, Snežana Katanski², Branko Milošević \\ ${ }^{1}$ Faculty of Agronomy, Čačak, University of Kragujevac, Serbia \\ ${ }^{2}$ Institute of Field and Vegetable Crops, Novi Sad, Serbia
}

\begin{abstract}
Alfalfa is the most important forage crop in Serbia grown for high yields of quality fodder. In order to expand alfalfa production on pseudogleys, research was conducted in the vicinity of Kraljevo. Results suggest the potential for growing alfalfa on acid soils in Serbia. The combined use of $2.5 \mathrm{t} \mathrm{ha}^{-1}$ and $5 \mathrm{t} \mathrm{ha}^{-1}$ lime and $30 \mathrm{tha}^{-1}$ manure on the pseudogley increases the soil $\mathrm{pH}$, humus content and available phosphorus and potassium levels, while decreasing the content of mobile aluminum, thus making the soil suitable for alfalfa production and high biomass yields (115.9 $\left.\mathrm{t} \mathrm{ha}^{-1}\right)$ during 3-4 years of stand utilization.
\end{abstract}

Key words: alfalfa, fertilization, lime, yield, cost-effectiveness

\section{Introduction}

Alfalfa as a forage crop is highly adapted to a range of soil and climatic conditions in Serbia. It is grown on about 200,000 ha, giving an average hay yield of $5.7 \mathrm{t} \mathrm{ha}^{-1}$ (SGS, 2011). However, the use of modern cultivars, fertilization, irrigation, weed, pest and disease control, proper utilization and cutting frequency

Received: 5 June 2015 / Accepted: 8 December 2015 
can lead to hay yields of 16-20 $\mathrm{tha}^{-1}$ during 4-5 years (Katić et al., 2010). Success in the production of high-quality alfalfa hay rich in proteins and minerals requires the use of appropriate cultural practices. Ensuring adequate nutrient supply through fertilization is a major technology-related factor in profitable alfalfa production (Lanyon and Griffith, 1988).

The first step preceding fertilization during stand establishment is soil analysis to evaluate the fertility status of soil and plan a nutrient management program. It is imperative to keep in mind that alfalfa harvest removes large amounts of nutrients from the soil, with $12 \mathrm{~kg}$ phosphorus and $25 \mathrm{~kg}$ potassium required per ton of dry matter (Đukić et al., 2009). Since alfalfa uptakes nitrogen from the atmosphere, low application rates of nitrogen fertilizers are recommended $\left(30-50 \mathrm{~kg} \mathrm{ha}^{-1}\right)$ during alfalfa stand establishment. Zinc, iron, copper, manganese and boron deficiencies rarely occur in soils in Serbia. Prior to micronutrient fertilization, soil or plant tissue should be tested for nutrient deficiencies (Katić et al., 2013). Calcium and magnesium deficiencies are rare in soils used for alfalfa production. However, acid soils require the use of lime materials for successful alfalfa production (Katić et al., 2009). Liming as an ameliorative intervention increases soil pH i.e. reduces soil acidity, thus leading to an increase in readily available phosphorus and potassium levels (Dugalić et al., 2011).

The use of liming materials is an essential practice in reducing $\mathrm{Al}, \mathrm{Fe}$ and $\mathrm{Mn}$ concentrations to levels that are not harmful to crops (Bošković-Rakočević and Bokan, 2005, Dugalić et al., 2008; Dugalić et al., 2011).

\section{Materials and methods}

In order to analyze the yield and stand life of alfalfa on a pseudogley, field trials were established at two locations, viz. at the experimental field of the Secondary School of Agriculture, Kraljevo, in 2004-2007, involving liming at two rates $3 \mathrm{t} \mathrm{ha}^{-1}$ and $6 \mathrm{t} \mathrm{ha}^{-1}$ as the main treatment (Katić et al., 2009), and at Dragčići in the Kraljevo region in 2009, involving 5 treatments: I) control (without liming); II) $2.5 \mathrm{t} \mathrm{ha}^{-1}$ lime; III) $5 \mathrm{t} \mathrm{ha}^{-1}$ lime; IV) $2.5 \mathrm{t} \mathrm{ha}^{-1}$ lime $+30 \mathrm{t}$ $\mathrm{ha}^{-1}$ manure and V) $5.0 \mathrm{t} \mathrm{ha}^{-1}$ lime $+30 \mathrm{t} \mathrm{ha}^{-1}$ manure. Primary tillage in the autumn of 2008 involved fertilization with $500 \mathrm{~kg}$ NPK 16:16:16 fertilizer i.e. 80 $\mathrm{kg} \mathrm{NPK} / \mathrm{ha}$. The acid psuedogley of the Kraljevo valley is characterized by high levels of $\mathrm{Al}^{3+}$ ions $\left(24.8 \mathrm{mg} / \mathrm{kg}\right.$ ) and $\mathrm{Mn}^{2+}$ ions $(46.4 \mathrm{mg} / \mathrm{kg}$ ) (Dugalić et al., 2008). Detailed soil chemical analyses, physical and mechanical properties of the soil and trial set-up techniques were described by Katić et al. (2009), Dugalić et al. (2011) and Bokan et al. (2010). Soil analysis (Tab. 1) at both locations shows similarity in chemical composition at 0-30 cm depth, except in available phosphorus levels which are $4.5 \mathrm{mg} / 100 \mathrm{~g}$ dry soil lower at Dragčići. 
Table 1. Characteristics of pseudogley soil in Kraljevo and Dragčići

\begin{tabular}{lccccccc}
\hline Location & $\begin{array}{c}\text { Depth } \\
(\mathrm{cm})\end{array}$ & $\mathrm{pH}$ & $\begin{array}{c}\mathrm{CaCO}_{3} \\
\%\end{array}$ & $\begin{array}{c}\text { humus } \\
\%\end{array}$ & $\begin{array}{c}\mathrm{N} \\
\%\end{array}$ & $\begin{array}{c}\mathrm{P}_{2} \mathrm{O}_{5} \\
\mathrm{mg} / 100 \mathrm{~g}\end{array}$ & $\begin{array}{c}\mathrm{K}_{2} \mathrm{O} \\
\mathrm{mg} / 100 \mathrm{~g}\end{array}$ \\
\hline Kraljevo & $0-30 \mathrm{~cm}$ & 4.79 & 0,00 & 2.56 & 0.13 & 7.20 & 11.00 \\
Dragčići & $0-30 \mathrm{~cm}$ & 4.82 & - & 2.51 & 0.16 & 2.7 & 12.6 \\
\hline
\end{tabular}

\section{Results and Discussion}

On the pseudogley in Kraljevo, during 2004-2007, the treatment with $3 \mathrm{t} \mathrm{ha}^{-1}$ of lime resulted in yields of $180.4 \mathrm{t} \mathrm{ha}^{-1}$ of green fodder or $44.4 \mathrm{t}$ of hay ha $\mathrm{ha}^{-1}$, while liming at a rate of $6 \mathrm{tha}^{-1}$ gave respective yields of $199.2 \mathrm{t} \mathrm{ha}^{-1}$ and 50,4 t $\mathrm{ha}^{-1}$ (Tab. 3). These yields are high and similar to those on neutral fertile soil (Katić et al., 2010). Liming extended the alfalfa stand life to 4 years and ensured yield stability during the year (Katić et al., 2009). Yield differences between the lime application rates were significant in the third and fourth years of plant life, and the analysis of economic effects in alfalfa hay production with liming included indicates an economic return (Katić et al., 2009).

Table 2. Total yields of alfalfa biomass $\left(\mathrm{t} \mathrm{ha}^{-1}\right)$ in Kraljevo (2004-2007)

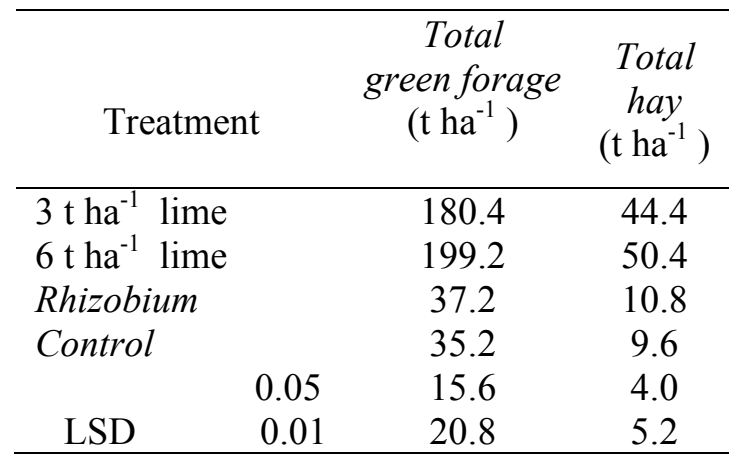

At the Dragčići location, on a fine-textured pseudogley, liming at $2.5 \mathrm{tha}^{-1}$ during 2009-2011 gave high yields of green forage - 84.4 $\mathrm{tha}^{-1}$ (Tab. 3) or about $16 \mathrm{t} \mathrm{ha}^{-1}$ i.e. $5.6 \mathrm{t} \mathrm{ha}^{-1}$ of hay annually, which is the average hay yield in Serbia (SGS 2011). The treatment with $5 \mathrm{t}$ of lime ha ${ }^{-1}$ resulted in higher yields of green forage (101.3 tha $\mathrm{th}^{-1}$ ) and hay $\left(20.3 \mathrm{t} \mathrm{ha}^{-1}\right)$, giving an annual yield of $6.7 \mathrm{t} \mathrm{ha}^{-1}$. However, alfalfa yields were the highest after the combined treatment with mineral fertilizers, lime and manure. The application rates of $2.5 \mathrm{t} \mathrm{ha}^{-1}$ for lime and $30 \mathrm{t} \mathrm{ha}^{-1}$ for manure gave forage yields of $111.8 \mathrm{tha}^{-1}$ or hay yields of $22.4 \mathrm{t}$ $\mathrm{ha}^{-1}$, with an average annual hay yield of about $7.5 \mathrm{t} \mathrm{ha}^{-1}$. 
Table 3. Yield of alfalfa green forage $\left(t \mathrm{tha}^{-1}\right)$ during 2009-2011 (Dragčići)

\begin{tabular}{|c|c|c|c|c|}
\hline Treatment & 2009 & 2010 & 2011 & $\begin{array}{c}\sum 2009- \\
2011\end{array}$ \\
\hline Control - 500 kg NPK & 11.5 & 4.1 & 0.0 & 15,6 \\
\hline NPK $500+2.5 \mathrm{tha}^{-1}$ lime & 16.3 & 50.3 & 17.8 & 84,4 \\
\hline NPK $500+5 \mathrm{t} \mathrm{ha}^{-1}$ lime & 18.8 & 57.0 & 25.4 & 101,3 \\
\hline $\begin{array}{l}\text { NPK } 500+2.5 \mathrm{t} \mathrm{ha}^{-1} \mathrm{Ca}+\text { manure } 30 \mathrm{t} \\
\mathrm{ha}^{-1}\end{array}$ & 21.4 & 63.4 & 27.0 & 111,8 \\
\hline $\begin{array}{l}\text { NPK } 500+5.0 \mathrm{tha}^{-1} \mathrm{Ca}+\text { manure } 30 \mathrm{t} \\
\mathrm{ha}^{-1}\end{array}$ & 21.7 & 61.6 & 32.5 & 115,9 \\
\hline Average & 17.9 & 47.3 & 20.5 & 85,8 \\
\hline CV \% & & & 22.0 & \\
\hline 0.05 & & 5.1 & & 8.7 \\
\hline LSD 0.01 & & 6.7 & & 11.7 \\
\hline
\end{tabular}

Liming at the higher application rate $\left(5 \mathrm{tha}^{-1}\right)$ combined with $30 \mathrm{t}$ of manure $\mathrm{ha}^{-1}$ gave green forage and hay yields of $115.9 \mathrm{tha}^{-1}$ and $23 \mathrm{t} \mathrm{ha}^{-1}$, respectively, over the three-year period or an annual hay yield of $7.7 \mathrm{t} \mathrm{ha}^{-1}$. No statistically significant differences were observed in green forage yield between low lime application rate + manure and high liming rate + manure treatments (Tab. 3 ). 
Table 4. Chemical composition of soil and plants in Kraljevo (Dugalić et al., 2008)

\begin{tabular}{|c|c|c|c|c|c|c|}
\hline \multirow{3}{*}{ Nutrient } & \multirow{2}{*}{\multicolumn{2}{|c|}{ Control }} & \multicolumn{2}{|c|}{ Treatment } & \multirow{2}{*}{\multicolumn{2}{|c|}{$6 \mathrm{tha}^{-1}$ lime }} \\
\hline & & & $3 \mathrm{th}$ & lime & & \\
\hline & Soil & Plant & Soil & Plant & Soil & Plant \\
\hline $\mathrm{P}_{2} \mathrm{O}_{5} \%$ & 0.0061 & 0.281 & 0.0191 & 0.395 & 0.0213 & 0.456 \\
\hline $\mathrm{K}_{2} \mathrm{O} \%$ & 0.065 & 1.99 & 0.0076 & 2.34 & 0.0085 & 3.05 \\
\hline $\mathrm{Ca} \%$ & 0.115 & 0.95 & 0.2186 & 1.15 & 0.3459 & 1.30 \\
\hline $\mathrm{Mg} \%$ & 0.0185 & 0.316 & 0.0722 & 0.291 & 0.0829 & 0.309 \\
\hline $\mathrm{Al} \mathrm{mg} / \mathrm{kg}$ & 23.9 & 89.98 & 18.5 & 50.63 & 15.4 & 44.24 \\
\hline $\mathrm{Fe} \mathrm{mg/kg}$ & 240.4 & 201.7 & 151.1 & 153.2 & 126.8 & 109.6 \\
\hline $\mathrm{Mn} \mathrm{mg/kg}$ & 43.8 & 72.47 & 40.6 & 61.66 & 38.9 & 53.24 \\
\hline $\mathrm{Zn} \mathrm{mg/kg}$ & 0.86 & 32.33 & 0.7 & 29.99 & 0.8 & 25.68 \\
\hline $\mathrm{Cu} \mathrm{mg/kg}$ & 0.25 & - & 1.6 & - & 1.7 & - \\
\hline $\begin{array}{l}\mathrm{B} \\
\mathrm{mg} / \mathrm{kg}\end{array}$ & 0.14 & - & 0.5 & - & 0.6 & - \\
\hline
\end{tabular}

Liming the pseudogley in the Kraljevo valley improves the soil $\mathrm{pH}$ and increases the concentration of readily available nutrients (Dugalić et al., 2011). Successful alfalfa production requires the use of liming materials to increase the levels of readily available $\mathrm{P}_{2} \mathrm{O}_{5}, \mathrm{~K}_{2} \mathrm{O}, \mathrm{Ca}$ and $\mathrm{Mg}$ (Tab 4.) and decrease the availability of Al, Fe $\mathrm{Mn}$ and $\mathrm{Zn}$ (Dugalić et al., 2008).

Growing alfalfa on the soil treated with lime $\left(3\right.$ and $\left.6 \mathrm{th}^{-1}\right)$ led to an increase in $\mathrm{P}$ content in the plant from $0.281 \%$ to $0.395 \%$ and 0.456 , respectively (Tab. 4). Moreover, potassium levels in the plant increased from $1.99 \%$ to $2.34 \%$ and $3.05 \%$, respectively, simultaneously with an increase in $\mathrm{Ca}$ content, while Fe, Mn and Zn levels decreased. Katić et al. (2013) provide soil P and $\mathrm{K}$ threshold values as a basis for alfalfa fertilization during stand establishment and utilization. Threshold values on soil nutrient contents should be set in the future to enable proper use of fertilizers based on nutrient removal by the alfalfa crop.

Nutrient requirements for alfalfa plants were analyzed using data from Canada, Government of Manitoba (2006). The comparison of the results in the 
present study with the threshold values suggests that sufficient $\mathrm{N}, \mathrm{P}$ and $\mathrm{K}$ levels were supplied by both lime application rates (Tab. 5). The content of sulfur was not determined since soils in Serbia exhibit no sulfur deficiencies. Furthermore, the contents of $\mathrm{Ca}, \mathrm{Fe}, \mathrm{Mn}$ and $\mathrm{Zn}$ were also found to be adequate for alfalfa plants. $\mathrm{Mg}$ content in the lime treatment at $3 \mathrm{t} \mathrm{ha}^{-1}$ was close to marginal and sufficient (Tab. 5). The levels of the micronutrients $\mathrm{B}$, Mo and $\mathrm{Cu}$ were not determined, but they should be covered by further research, given their importance for alfalfa.

Table 5. Criteria for evaluating the nutritional status of alfalfa plants

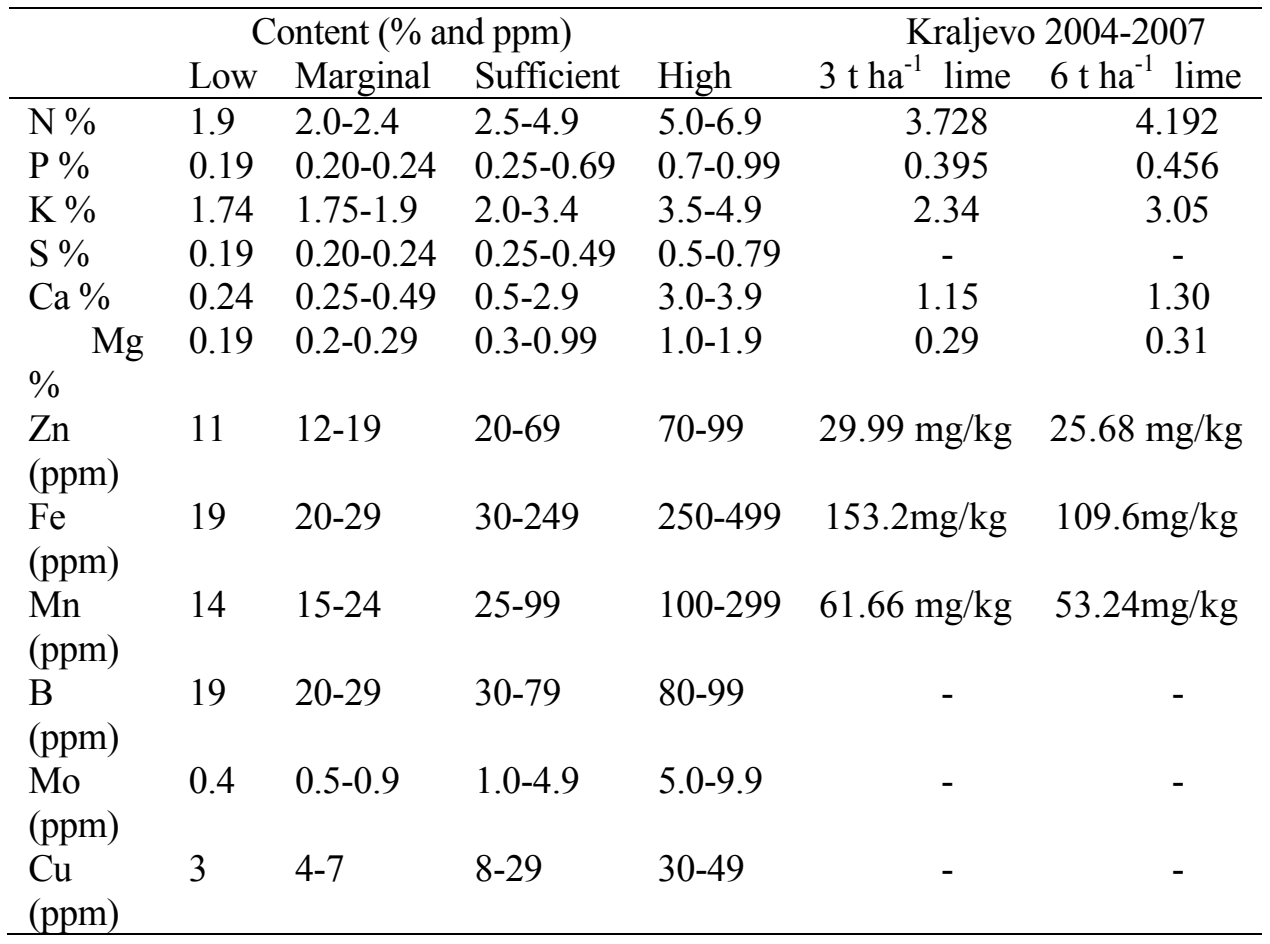

The massive use of mineral fertilizers leads to price increases. This demands an analysis of the economic effects of mineral fertilization. Orloff et al. (2009) and Katic et al. (2009) suggest monitoring the prices of mineral fertilizers and alfalfa hay. Namely, at high fertilizer prices, greater hay yield benefits are required to justify fertilizer applications. However, at low hay prices, fertilizer efficiency is reduced (Katić et al., 2013).

The analysis of the economic effects of mineral fertilization and liming in alfalfa hay production shows that the highest price of hay was in the first year (RSD 34.0) due to the highest costs associated with stand establishment (Katic et al., 
2013). Lower hay prices were observed in the second and third years of stand utilization (RSD 5.7 and 9.7, respectively). The average price of $1 \mathrm{~kg}$ hay for the 2009-2011 period at the Dragčići location was RSD 12.8. This price should be considered in planning the use of hay on either one's own farm or for the market. It the market price approaches the price of hay produced, production costs should be reduced. With mineral fertilizer costs accounting for a significant percentage of production costs, this reduction consequently increases fertilizer efficiency i.e. lowers fertilizer inputs in livestock farming calculations. However, in these analyses, in addition to considering current prices, price forecasts should be made for the coming year, using data on the situation in livestock farming (number of animals) i.e. fodder requirements for the coming year and last year's hay stock.

\section{Conclusion}

The results suggest the potential to expand alfalfa production on pseudogleys in Serbia.

Using mineral fertillizers alone for alfalfa fertilization has no effect on the agrochemical properties of pseudogleys, but the addition of lime leads to a significant increase in alfalfa yield.

The combined application of $2.5 \mathrm{tha}^{-1}$ and $5 \mathrm{t} \mathrm{ha}^{-1}$ lime and $30 \mathrm{tha}^{-1}$ manure on the pseudogley increases the soil $\mathrm{pH}$, humus content and available phosphorus and potassium levels, while decreasing the content of mobile aluminum, thus making the soil suitable for alfalfa production and high biomass yields (115.9 $\mathrm{t} \mathrm{ha}^{-1}$ ) during 3-4 years of stand utilization.

When growing alfalfa on acid soils, the cost-effectiveness of mineral fertilizer and lime applications should be considered, along with the expectation that the initial high cost associated with stand establishment will be reduced in the coming years of stand utilization.

\section{Acknowledgment}

Research presented in this paper are part of Project TR 31024 "Increasing the market significance of forage crops by breeding and optimizing seed production technology" funded by the Ministry of Education, Science and Technological Development, Republic of Serbia. 


\section{References}

B o k a n N., D u ga 1 i ć G., K a t i ć S., M i 1 i ć D. i V a s i ljević S. (2010): Uticaj đubrenja pseudogleja na prinos lucerke u zasnivanju. Zbornik radova XV Savetovanja o biotehnologiji. Čačak 26-27.03.2010. 301-306.

Government of Manitoba (2006): Fertilizing Alfalfa Forage. www.gov.mb.ca https://www.gov.mb.ca/agriculture/crops/forages/pdf/bjb05s01.pdf

B o š k ovi ć - R a k o č e vi ć L J., B o k a n N. (2005): Neutralizing Acid Soils for the Indispensable Microelements Mobility. Acta Agriculturae Serbica, Čačak, Vol.X, $20,23-28$.

D u g a 1 i ć G., G a j i ć B., K a t i ć S. and S t e vo vi ć V. (2008): Influence of liming on yield and chemical composition of alfalfa on acid soils. Proceedings of the VII.ALPS-ADRIA Scientific Workshop. Stara Lesna, Slovakia, 28. May - 2 May 2008. Cereal Research Communications, 36, II, 995-998

D u g a 1 i ć D., B o k a n N., K a t i ć S., J e 1 i ć M. (2011): Uticaj kreča i stajnjaka na promene agrohemijskih osobina pseudogleja. Agroznanje. Vol. 12, br. 469-474.

Đ u k i ć D., S t e v o v i ć V., J a n j i ć V. (2009): Proizvodnja stočne hrane na oranicama i travnjacima. Poljoprivredni fakultet, Novi Sad, Agronomski fakultet, Čačak, 592, ISBN 978-86-87611-03-0

K a t i ć S., M i 1 i ć D., L a z a r e vi ć B., D u g a 1 i ć G. i B o k a n N. (2009): Stabilnost prinosa i dužina života lucerke na pseudogleju posle primene krečnjaka. Ratar. Povrt. / Field Veg. Crop 46 (I): 81-88.

K a t i ć S., M i 1 i ć D., M i h a i 1 o vi ć V, K a r a g i ć Đ, i P o j i ć M. (2010): Prinos, komponente prinosa i svarljivost suve materije eksperimentalnih populacija lucerke. Ratar. Povrt. / Field Veg. Crop Res, 47 (1): 209-216.

K a t i ć S., M i 1 i ć D., K a r a g i ć Đ., M a 1 i d ž a G., K a t a n s k i, S. (2013): Ublažavanje negativnih efekata suše na prinos lucerke primenom agrotehničkih mera. Zbornik referata, 47. Savetovanje agronoma Srbije, Zlatibor, Institut za ratarstvo i povrtarstvo, Novi Sad, 183-193.

K a tić S., M i li ć D., V a s i 1 je vić S., K a t a n s k i S., D ugalić G., B ok a n N. (2013): Efekti đubrenja na prinos i ekonomičnost proizvodnje sena lucerke. Zbornik radova, XVIII Savetovanje o biotehnologiji sa međunarodnim učešćem, Agronomski fakultet Čačak 15.-16. mart. 18 (20): 243-250.

L a $\mathrm{n}$ y o $\mathrm{n}$ L. E, and G r i f f i t h W. K. (1988): Nutrition and fertilizer use. p. 333-372. In A.A. Hanson, et al. (ed.). Alfalfa and alfalfa improvement. Agron. Monogr. 29. ASA, Madison, WI.

O r 1 o f f S, P u t n a m D, W i 1 s o n R (2009): Is it worth fertilizing alfalfa with current fertilizer prices. WSHGA Annual Conference Proceedings, January 14-15, Kennewick, WA. http://www.zasav.org.rs/

Statistički godišnjak Srbije (2011). 


\title{
PRINOS I EKONOMIČNOST PROIZVODNJE SENA LUCERKE U ZAVISNOSTI OD ĐUBRENJA
}

\author{
Nikola Bokan', Goran Dugalić ${ }^{1}$, Slobodan Katić ${ }^{2}$ Dragan Milić², \\ Sanja Vasiljevićc ${ }^{2}$, Snežana Katanski², Branko Milošević \\ ${ }^{1}$ Agronomski fakultet $u$ Čačku, Univerzitet u Kragujevcu \\ ${ }^{2}$ Institut za ratarstvo i povrtarstvo, Novi Sad, Srbija
}

\begin{abstract}
Rezime
Lucerka je najznačajnija krmna biljka u Srbiji jer daje visoke prinose kvalitetne kabaste stočne hrane, koja se najviše koristi u ishrani preživara, uglavnom kao seno. Zbog izuzetne osetljivosti na niske $\mathrm{pH}$ vrednosti zemljišta, u cilju proširenja areala, lucerka je gajena na pseudogleju, na području Kraljeva.

Đubrenje lucerke samo mineralnim đubrivima ne utiče na promenu agrohemijskih osobina pseudogleja, ali se dodavanjem kreča prinos lucerke značajno povećava.

Rezultati ukazuju na mogućnost gajenja lucerke na ovom tipu zemljišta uz odgovarajuće đubrenje. Primenom 2,5 $\mathrm{tha}^{-1}$ i $5 \mathrm{t} \mathrm{ha}^{-1}$ kreča u kombinaciji sa $30 \mathrm{t}$ $\mathrm{ha}^{-1}$ stajnjaka na pseudogleju se povećava $\mathrm{pH}$ vrednost zemljišta, raste sadržaj humusa, pristupačnog fosfora i kalijuma, i smanjuje se sadržaj mobilnog aluminijuma, što ga čini podesnim za gajenje lucerke i postizanje visokih prinosa biomase $\left(115,9 \mathrm{t} \mathrm{ha}^{-1}\right)$ tokom perioda iskorišćavanja od 3-4 godine.

$\mathrm{U}$ gajenju lucerke na kiselim zemljištima, mora se voditi računa $o$ ekonomičnosti primene mineralnih đubriva i kreča.
\end{abstract}

Ključne reči: lucerka, đubrenje, kreč, prinos, ekonomičnost 